\title{
PENGARUH STRATEGI PEMBELAJARAN AKTIF VIDEO KRITIK TERHADAP PERHATIAN DAN HASIL BELAJAR PESERTA DIDIK PADA MATERI PELAJARAN PEMANASAN GLOBAL
}

\author{
Rachmawati $^{(1)}$; Leonardo Elisa Aisoi ${ }^{(2)}$ \\ ${ }^{1}$ Program Studi Pendidikan Biologi FKIP UNCEN; watirachma1531@ gmail.com \\ ${ }^{2}$ Program Studi Pendidikan Biologi FKIP UNCEN; leon_aisoi@yahoo.com
}

\begin{abstract}
The aim of this study was to find out (1) To know the influence of active learning strategy video critic to students' attention on the subject material global warming in grade VII of SMP Muhammadiyah Jayapura. (2). To know the influence of active learning strategy video critic to students' learning result on the subject material global warming in grade VII of SMP Muhammadiyah Jayapura. The kind of the research is quantitative.The research design used is Quasi Experimental Design in the form of Nonequivalent Control Group Design. The population is all students grade VII of SMP Muhammadiyah Jayapura. The taking of sample is conducted with the technique of purposive sampling. And class VII D as the class control and VII D as class experiment. The instruments used are survey, observation, and objective test questions. The data is analyzed with the simple regression test. The result of the researchshows that : (1) There is significant influence to students's attention in following learning process by using active learning strategy of video critic with the score of $t_{\text {counting }}$ is bigger than $t_{\text {table }}(2,90>2,045)$. (2) There is significant influence between the students' learning result in the class experiment by using the active learning strategy video critic with the score of $t_{\text {counting }}$ is bigger than $t_{\text {table }}(2,292>2,045)$.
\end{abstract}

Keywords : The learning strategy of video critic; Attention, learning; Global warming.

\begin{abstract}
ABSTRAK
Penelitian ini bertujuan (1) Untuk mengetahui pengaruh strategi pembelajaran aktif video kritik terhadap perhatian peserta didik pada Materi Pelajaran Pemanasan Global di kelas VII SMP Muhammadiyah Jayapura. (2) Untuk mengetahui pengaruh strategi pembelajaran aktif video kritik terhadap hasil belajar peserta didik pada Materi Pelajaran Pemanasan Global di kelas VII SMP Muhammadiyah Jayapura. Jenis penelitian ini adalah penelitian kuantitatif. Desain penelitian yang digunakan Quasi Experimental Design bentuk Nonequivalent Control Group Design. Populasi pada penelitian ini adalah seluruh peserta didik kelas VII SMP Muhammadiyah Jayapura. Penentuan sampel dilakukan dengan Teknik purposive sampling dan diperoleh kelas VII D sebagai kelas kontrol dan VII E sebagai kelas eksperimen. Instrumen yang digunakan adalah angket, observasi, dan soal tes objektif. Data yang diperoleh dianalisis dengan uji regresi sederhana.Hasil penelitian ini menunjukkan bahwa: (1) Terdapat pengaruh yang signifikan penggunaan strategi pembelajaran video kritik terhadap perhatian peserta didik dalam mengikuti proses pembelajaran dengan nilai $t_{\text {hitung }}$ lebih besar dari $t_{\text {tabel }}(2,960>2,045)$. (2) Terdapat pengaruh yang signifikan antara penggunaan strategi pembelajaran video kritik dengan hasil belajar peserta didik pada kelas eksperimen dengan nilait $t_{\text {hitung }}$ lebih besar dari $t_{\text {tabel }}(2,292>2,045)$.
\end{abstract}

Kata Kunci : Strategi Pembelajaran Aktif Video Kritik; Perhatian; Pemanasan Global. 


\section{PENDAHULUAN}

Berdasarkan hasil observasi dan wawancara dengan guru bidang studi IPA Biologi kelas VII SMP Muhammadiyah Jayapura tanggal 27 Agustus 2018, diperoleh informasi bahwa masalah yang sering dihadapi guru adalah kurangnya perhatian peserta didik dalam proses pembelajaran, peserta didik lebih asyik dengan aktivitasnya sendiri dan mengobrol dengan teman sebangku. Hal ini dapat terlihat dari rendahnya keaktifan peserta didik dalam melakukan aktivitas pembelajaran di kelas. Saat proses pembelajaran berlangsung peserta didik tidak fokus saat guru menerangkan pelajaran, kurang aktif dalam bertanya, bermain dan bercerita sendiri, peserta didik jenuh melihat power point yang hanya berupa tulisan terlalu lama. Guru menduga, peserta didik lebih senang melihat gambargambar, video atau demonstrasi secara langsung, karena dengan itu peserta didik akan lebih fokus dan memperhatikan guru saat mengajar.

Hasil wawancara guru mengatakan masih banyak peserta didik yang belum memahami materi pemanasan global sehingga mempengaruhi hasil belajar yang rendah dibawah kriteria ketuntasan minimum (KKM) yaitu 65. Materi pemanasan global termasuk materi yang tergolong sulit bagi peserta didik. Kendala peserta didik sulit memahami maupun sulit untuk mengingat apa yang disampaikan oleh guru,karena terdapat istilah efek rumah kaca dan proses pemanasan global yang sulit dijelaskan tanpa adanya media perantara selain buku paket yang dimiliki oleh peserta didik.

Buku paket yang digunakan peserta didik yaitu buku paket PR IPA pegangan peserta didik, didapati bahwa buku paket tersebut yang digunakan untuk menyampaikan pemanasan global sudah dilengkapi oleh contoh-contoh gambar efek rumah kaca dan proses terjadinya pemanasan global, namun gambar tersebut kurang jelas karena hanya berdasar hitam putih, sehingga bersifat abstrak, di dalam buku paket peserta didik tersebut juga teks materi pemanasan global sangat ringkas baik penjelasan mengenai efek rumah kaca, penyebab terjadinya pemanasan global, dan dampak serta upaya menanggulangi pemanasan global, maka untuk menunjang konsep yang abstrak tersebutdiperlukan penggunaan sebuah media lain yaitu media audio visual atau video.

Materi pemanasan global merupakan materi yang secara langsung terjadi pada kehidupan sehari-hari baik di lingkungan masyarakat sekitar maupun secara global dan dapat dirasakan oleh setiap makhluk hidup. Proses pemanasan global tidak 
dapat dilihat secara langsung, oleh karena itu perlu adanya suatu gambaran yang menjelaskan proses terjadinya pemanasan global yang berdampak pada seluruh dunia.

Kemampuan video untuk mengabadikan kejadian-kejadian fakta dalam bentuk program dokumenter bermanfaat untuk membantu pengajar dalam mengemukakan fakta, kemudian membahas fakta tersebut secara lebih jelas dan mendiskusikannya diruang kelas (Uno B. 2017).

Salah satu strategi pembelajaran yang diajukan untuk mengatasi kejenuhan, memacu keaktifan peserta didik dan memudahkan peserta didik memahami materi pelajaran adalah dengan menggunakan strategi pembelajaran aktif video kritik. Melihat video-video pendidikan merupakan persoalan pasif. Para peserta didik duduk ditempat duduk masing-masing, dengan menunggu untuk dihibur. Ini adalah suatu cara aktif untuk membuat para peserta didik menyaksikan suatu video (Sibermen M., 2007).

Penggunaan media pembelajaran bentuk video dipandang tepat untuk memberikan pemahaman yang bersifat nyata karena mengggunakan dua aspek yaitu audio dan visual, sehingga mempermudah peserta didik memahami materi yang disampaikan. Materi yang dipahami akan disampaikan kembali pada diskusi pojok kritik kemudian diadakan jajak pendapat melalui strategi video kritik sehingga semua peserta didik memiliki suatu konsep pemahaman yang sama.

Strategi video kritik merupakan salah satu strategi yang terdapat dibuku Active Learning karya (Sibermen M., 2007). Strategi yang melibatkan video-video pendidikan yang sesuai materi ajar agar peserta didik tidak mengalami kejenuhan dalam menerima suatu pembelajaran. Peserta didik dituntut untuk turut aktif dalam pembelajaran ini karena sambil menonton, peserta didik diminta untuk mengomentari suatu video yang ditayangkan oleh guru.

Strategi menjadi kritikus tayangan video merupakan salah strategi yang menjadikan peserta didik aktif dan kreatif dalam proses pembelajaran, dengan melibatkan peserta didik menjadi kritikus tayangan video yang berkaitan dengan materi pembelajaran akan menjadikan peserta didik berpikir dalam mengeluarkan pendapat. Peserta didik ikut terlibat dalam proses pembelajaran, saling interaksi akan terjalin baik antar peserta didik dan guru serta antar peserta didik dan peserta didik lainnya, sehingga aktivitas belajar peserta didik yang diperoleh akan lebih meningkat. Dengan interaksi dan partisipasi peserta didik dalam proses pembelajaran maka akan terwujudilmu pengetahuan yang berkualitas (Widiawati, 2014). Dengan penggunaan media yang tepat, maka akan meningkatkan perhatian peserta didik 
dalam mengikuti proses pembelajaran tersebut.Perhatian dapat diartikan dengan kesadaran atau aktivitas psikis yang tertuju pada satu objek. Perbedaan itu terletak pada hal-hal berikut (Ngalimun, dkk., 2016). Intensitas perhatian; Luasnya objek perhatian; Lamanya perhatian.

Menurut Sanjaya HW. (2006), kerucut pengalaman yang dikemukakan oleh Edgar Dale memberikan gambaran bahwa pengalaman belajar yang diperoleh peserta didik dapat melalui proses perbuatan atau mengalami sendiri apa yang dipelajari, proses mengamati dan mendengarkan melalui media tertentu dan proses mendengarkan melalui Bahasa.

Menurut Sudjana, 2006) hasil belajar adalah kemampuan yang dimiliki peserta didik setalah menerima pengalaman proses belajarnya. Hasil belajar merupakan objek penilaian yang hakikatnya menilai penguasaan peserta didik terhadap tujuan instruksional yang menggambarkan penguasaan berupa kemampuan peserta didik setelah menerima atau menyelesaikan pengalaman proses pembelajarannya.

Berdasarkan latar belakang di atas, maka telah dilakukan penelitian dengan judul Pengaruh Strategi Pembelajaran Aktif Video Kritik terhadap Perhatian Peserta didik pada materi pelajaran pemanasan global di kelas VII SMP Muhammadiyah Jayapura.

\section{METODE PENELITIAN}

Metode penelitian yang digunakan adalam metode Eksperimen dengan jenis penelitian ini adalah kuantitatif, dengan Quasi Experimental Design (eksperimental semu) dengan kelas control dan kelas eksperimen. Dalam desain penelitian ini, kedua kelas diberi pretest dengan test yang sama. Kelas eksperimen diberi perlakuan strategi pembelajaran kelas aktif Video Kritik, sedangkan kelas kontrol adalah kelas lain yang diberi pembelajaran dengan model konvensional. Untuk melihat pengaruh strategi pembelajaran aktif video kritik terhadap perhatian peserta didik, maka digunakan angket dan hasil observasi. Sedangkan untuk melihat hasil belajar pada kedua kelas, maka pada awal dan akhir pembelajaran, kedua kelas diberi test (pretest dan posttes) yang sama.

Sampel dalam penelitian ini adalah peserta didik kelas VII D dan kelas VII E SMP Muhammadiyah Jayapura sebanyak 68 orang peserta didik, teknik pemilikan sampel penelitian secara purposive sampling.

Data yang diperoleh di analisis per parameter, perhatian siswa, data perhatian belajar peserta didik selama pembelajaran dengan menggunakan strategi pembelajaran video kritik sebagai sumber belajar bagi peserta didik dianalisis dengan cara menggunakan rumus rata-rata skor. Parameter pengaruh strategi pembelajaran aktif video kritik terhadap hasil belajar di 
analisis secara deskriptif kuantitatif dengan persentase, menggunakan Uji Prasyarat, yaitu Uji Normalitas data dan Uji Homogenitas, sedangkan untuk uji hipotesis dengan regresi sederhana dan Uji $t$ (t-test).

\section{HASIL DAN PEMBAHASAN}

\section{Pengaruh Video Kritik Terhadap Perhatian Peserta didik}

Tabel 1. Hasil Regresi SederhanaData variabel $\mathrm{X}$ terhadap $\mathrm{Y}_{1}$ Coefficients $^{\text {a }}$

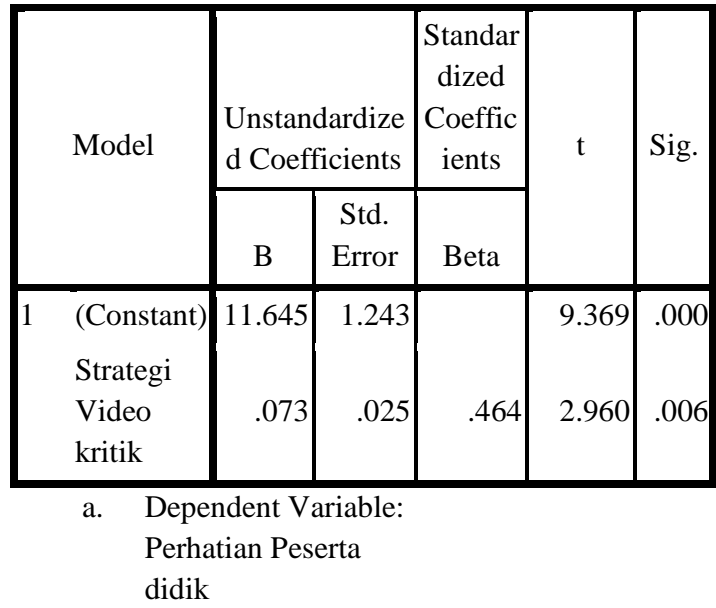

Berdasarkan tabel 1 di peroleh rumus sebagai berikut: $\hat{Y}=11,645+$ 0,073X. Pada tabel 1diketahui hasil Constan (a) sebesar 11,645 sedangkan perhatian peserta didik (b) sebesar 0,073. Nilai ini menunjukkan arah hubungan dari strategi pembelajaran video kritik dengan perhatian peserta didik Sehingga dapat disimpulkan bahwa semakin baik strategi pembelajaran video kritik maka perhatian akan semakin meningkat. Hal ini dapat dilihat dari nilai koefisien regresinya yang bernilai positif.
Berdasarkan analisis regresi linear sederhana dengan menggunakan bantuan SPSS 16, menunjukkan adanya pengaruh yang signifikan terhadap perhatian peserta didik dalam mengikuti proses pembelajaran dengan menggunakan strategi pembelajaran aktif video kritik. Hal ini dapat diamati saat proses pembelajaran berlangsung di kelas eksperimen, peserta didik terlihat lebih aktif, dan berkonsentrasi dalam mengikuti kegiatan belajar mengajar.

Hasil dari uji regresi, diperoleh nilai $t_{\text {hitung }}$ lebih besar dari $t_{\text {tabel }}(2,960$ >2,045), maka $H_{0}$ ditolak sehingga dapat disimpulkan terdapat pengaruh yang signifikan antara strategi pembelajaran aktif video kritik terhadap perhatian peserta didik. Hal ini sejalan dengan penelitian yang pernah dilakukan oleh Rinaldy M., (2018), untuk mengetahui Hubungan Perhatian Peserta didik Dalam Mengikuti Proses Belajar Mengajar (PBM) Dengan Hasil Belajar Pada Mata Pelajaran Sejarah Peserta didik Kelas XI IPS SMA Negeri 1 Gunung Sugih Tahun Ajaran 2017/2018. Semakin tinggi perhatian peserta didik dalam mengikuti proses belajar mengajar (PBM) akan menyebabkan hasil belajarnya menjadi tinggi. 


\section{Pengaruh Video Kritik Terhadap Hasil Belajar.}

Tabel 2. Hasil Regresi Sederhana Data Variabel $\mathrm{X}$ terhadap $\mathrm{Y}_{2}$ Coefficients $^{\mathrm{a}}$

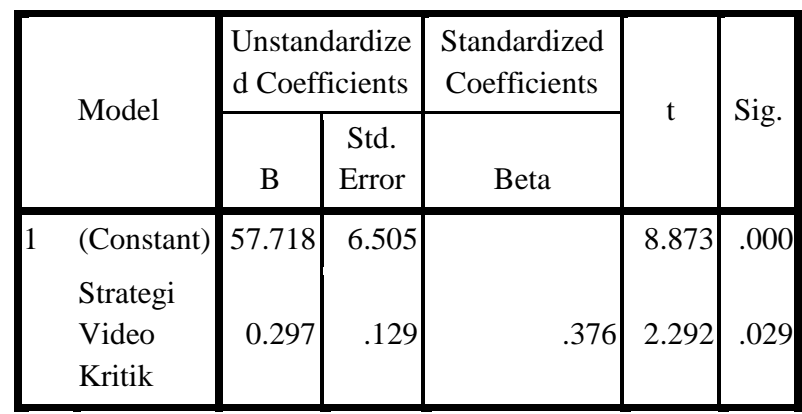

a. Dependent Variable:

Hasil Belajar

Berdasarkan tabel 2 di peroleh rumus sebagai berikut: $\hat{Y}=57.718+0$, .297X. Hasil Constant strategi video kritik (a) sebesar 57.718 sedangkan hasil belajar (b) sebesar 0,297. Nilai ini menunjukkan arah hubungan dari strategi pembelajaran video kritik dengan hasil belajar peserta didik Sehingga dapat disimpulkan bahwa semakin baik strategi pembelajaran video kritik maka hasil belajar peserta didik akan semakin meningkat. Hal ini dapat dilihat dari nilai koefisien regresinya yang bernilai positif.

Berdasarkan analisis regresi linear sederhana dengan menggunakan bantuan SPSS 16, disimpulkan bahwa terdapat pengaruh strategi pembelajaran aktif video kritik terhadap hasil belajar peserta didik. Hasil uji regresi kedua menunjukkan nilai $t_{\text {hitung }}$ lebih besar dari $t_{\text {tabel }}(2,292$ >2,045), maka $\mathrm{H}_{\mathrm{o}}$ ditolak sehingga dapat disimpulkan bahwa terdapat pengaruh yang signifikan antara hasil belajar peserta didik pada kelas eksperimen dengan menggunakan strategi pembelajaran aktif video kritik. Hasil belajar peserta didik dilihat dari selisih nilai rata-rata hasil belajar antara kelas eksperimen dan kelas kontrol.

Perolehan rata-rata hasil belajar kelas eksperimen setiap pertemuan dengan menggunakan strategi pembelajar video kritik (Gambar 1).:

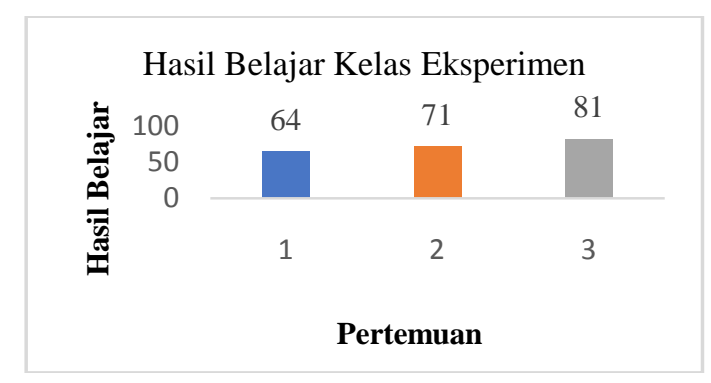

Gambar 1. Nilai Rata-Rata Hasil Belajar Kelas Eksperimen.

Perolehan rata-rata hasil belajar kelas kontrol setiap pertemuan dengan menggunakan metode ceramah / konvensional (Gambar 2) :

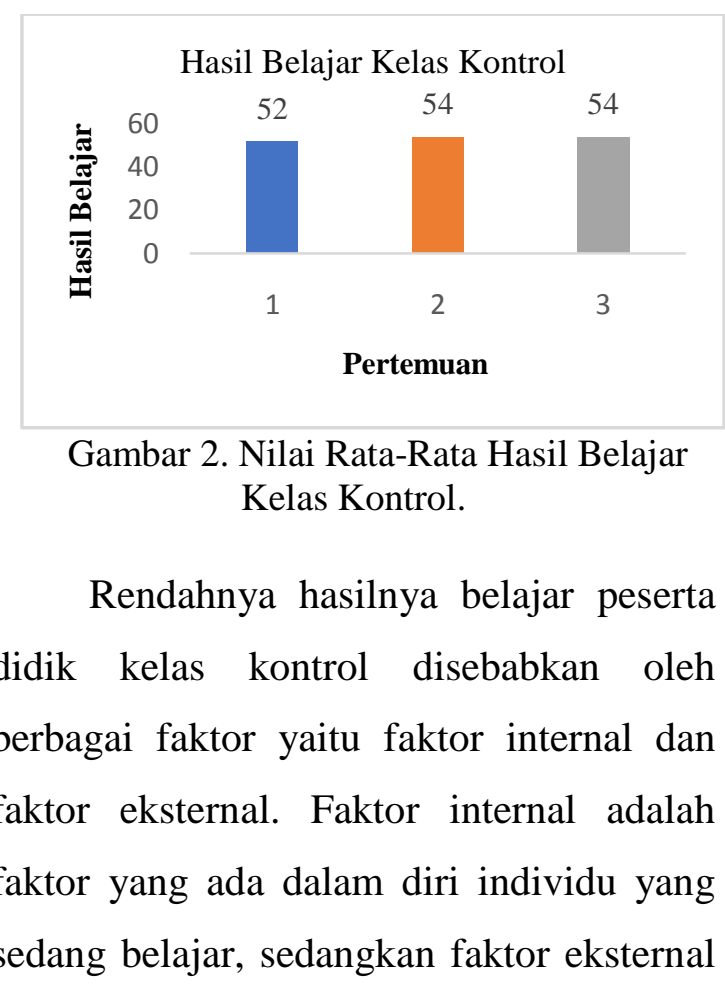


adalah faktor diluar sekolah (Slameto,D., 2015).

Tabel 3. Hasil Belajar Kelas Eksperimen dan Kelas Kontrol

\begin{tabular}{|ll|r|r|r|r|}
\hline \multicolumn{7}{|c|}{ Group Statistics } \\
\hline & Kelas & $\mathrm{N}$ & Mean & $\begin{array}{l}\text { Std. } \\
\text { Dev }\end{array}$ & $\begin{array}{c}\text { Std. Err } \\
\text { Mean }\end{array}$ \\
\hline $\begin{array}{l}\text { Hasil } \\
\text { Belajar } \\
\text { Biologi }\end{array}$ & Kelas & 34 & 72.02 & 11.32 & 1.94 \\
& $\begin{array}{l}\text { Kelas } \\
\text { Kontrol }\end{array}$ & 34 & 53.08 & 10.24 & 1.75 \\
\hline
\end{tabular}

Berdasarkan tabel 3, hasil penelitian uji $\mathrm{t}$ (t-test dua sampel) menunjukkan adanya peningkatan hasil belajar peserta didik, dengan nilai rata-rata hasil belajar kelas eksperimen adalah 72,02 dan kelas kontrol sebesar 53,08. Perbedaan rata-rata hasil belajar peserta didik antara dua kelas tersebut menunjukkan bahwa pembelajaran dengan menggunakan strategi pembelajaran aktif Video Kritik lebih baik dari yang menggunakan pembelajaran konvensional.

Tabel 4. Hasil Uji $t$ ( $t$ test)

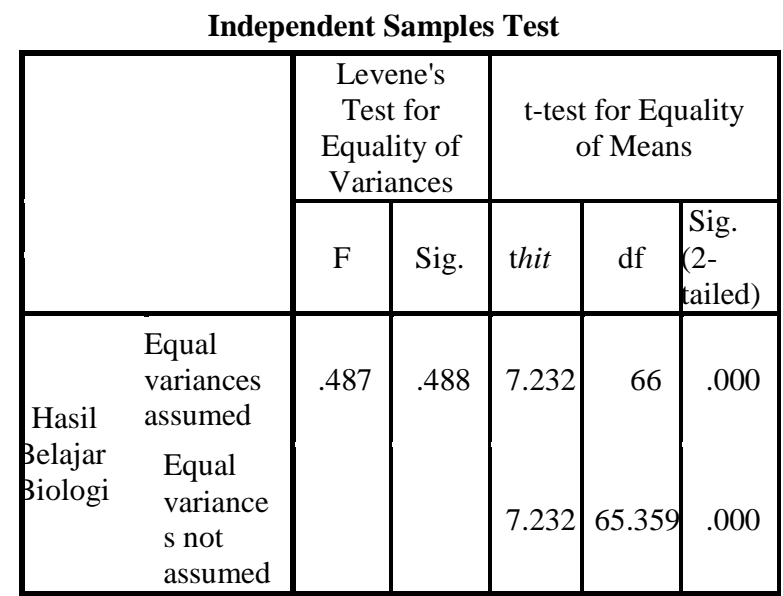

Perbedaan tersebut juga terlihat dari data analisis menggunakan uji t ( $t$-test dua sampel) menggunakan bantuan SPSS 16 pada tabel 4, menunjukkan nilai $t_{\text {hitung }}$ hasil belajar kelas eksperimen dan kelas kontrol lebih besar dari $t_{\text {tabel }}(7,232$ $>1,999)$, artinya terdapat perbedaan nilai rata-rata antara kelas eksperimen dan kelas kontrol. Berdasarkan hasil analisis tersebut maka dapat disimpulkan bahwa hasil belajar di kelas eksperimen lebih tinggi dari pada kelas kontrol. Menurut hasil penelitian Novita PR., (2017), hasil pengujian hipotesis menggunakan uji-t diperoleh bahwa nilai $t_{\text {hitung }} \geq t_{\text {tabel }}$ yaitu $29,22 \geq 2,0085$. Hasil penelitian yang sudah dilakukan menunjukkan bahwa terdapat perbedaan hasil belajar peserta didik. Hasil belajar peserta didik pada kelas eksperimen dan kelas kontrol terjadi perbedaan dikarenakan peserta didik pada kelas eksperimen lebih aktif dari pada kelas kontrol. Hal ini disebabkan karena penggunaan animasi, gambar dan suara dalam penjelasan yang sangat menarik dan menyenangkan sehingga membuat peserta didik lebih yakin dan termotivasi untuk mengetahui lebih lanjut tentang materi koloid. Hal ini dapat diibandingkan dengan kelas kontrol yang hanya menjelaskan materi tentang materi koloid dengan menggunakan metode ceramah saja, sehingga membuat peserta didik sangat merasa bosan dalam belajar. Pada kelas eksperimen kerja sama peserta didik dalam belajar dan menjawab pertanyaan lebih tinggi dari kelas kontrol. 


\section{SIMPULAN DAN SARAN}

SIMPULAN

Adanya pengaruh strategi pembelajaran aktif video kritik yang signifikan terhadap perhatian peserta didik dibuktikan dengan $t_{\text {hitung }}$ lebih besar dari $t_{\text {tabel }}(2,960>2,045)$, jugaterdapat pengaruh strategi pembelajaran aktif video kritik yang signifikan antara hasil belajar peserta didik pada kelas eksperimen, dibuktikan dengan $t_{\text {hitung }}$ lebih besar dari $t_{\text {tabel }}(2,292>2,045)$.

\section{SARAN}

Diharapkan hasil penelitian ini dapat dijadikan sebagai salah satu dari sekian banyak informasi dalam rangka meningkatkan hasil belajar peserta didik dan hendaknya guru bidang studi Biologi dapat menerapkan strategi pembelajaran aktif video kritik sebagai salah satu strategi dalam pembelajaran Biologi dan disesuaikan dengan materi pelajarannya.

\section{UCAPAN TERIMAKSIH}

Kami sampaikan terimakasih kepada Kepala Sekolah SMP Muhammadiyah Jayapura atas dukungannya memberi tempat dalam penelitian ini sehingga dapat berjalan dengan baik dan lancar

\section{DAFTAR PUSTAKA}

Ngalimun, Fauzani M, Salabi A, 2016 Strategi dan Model Pembelajaran Yogyakarta, Aswaja Pressindo;
Novita PR , 2017Pengaruh Pemanfaatan Media Video terhadap Hasil Belajar Peserta didik pada Materi Koloid di Kelas XI SMAN 10 Aceh Barat Daya, In Skripsi, Darussalam Banda Aceh, Universitas Islam Negeri ArRaniry;

Rinaldy M, 2018, Hubungan Perhatian Peserta didik dalam Mengikuti Proses Belajar Mengajar dengan Hasil Belajar pada Mata Pelajaran Sejarah Kelas XI IPS SMA Negeri 1 Gunung Sugih Tahun Ajaran 2017/2018, In Skripsi, Bandar Lampung, Universitas Lampung;

Sanjaya HW, 2006, Strategi Pembelajaran Berorientasi Standar Proses Pendidikan Jakarta, Kencana,;

Silbermen M, 2007Active Learning 101 Strategi Pembelajaran Aktif Sarjuli, Ammar A, Sutrisno, Ahmad ZA, Muqowin, editors. Yogyakarta: Pustaka Insan Madani;

Slameto D, 2015, Belajar dan faktor-faktor yang Mempengaruhi Jakarta, PT Rineka Cipta;

Sudjana N, 2006, Penilaian Hasil Proses Belajar Mengajar Bandung, PT Remaja Rosdakarya,

Uno B, 2017, Profesi KePendidikan Jakarta, PT Bumi Aksara;

Widiyawati, 2014, Efektivitas Strategi Video Critic dalam Pembelajaran Pendidikan Agama Islam untuk Meningkatkan Minat Belajar Peserta didik Kelas X SMK N 1 Tempel Tahun Ajaran 2013/2014, In Skripsi, Yogyakarta: Universitas Islam Negeri Sunan Kalijaga. 